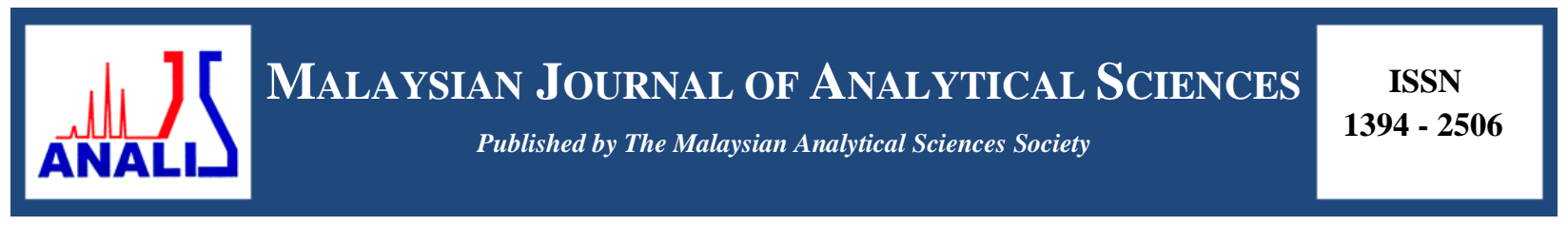

\title{
IMMOBILIZED METAL AFFINITY CHROMATOGRAPHIC MEMBRANE FOR TRYPSIN SEPARATION
}

\author{
(Membran Kromatografi Afiniti Logam Dipegun untuk Pemisahan Tripsin) \\ Sofiah Hamzah ${ }^{1}$, Nurul Hidayati Mat Alim ${ }^{1}$, Nurul Fakhriah Ismail ${ }^{1}$, Norhafiza Ilyana Yatim ${ }^{2}$, \\ Nur A'lya Mohd Sani ${ }^{1}$ \\ ${ }^{1}$ School of Ocean Engineering \\ ${ }^{2}$ School of Marine and Environmental Sciences \\ Universiti Malaysia Terengganu, 21030 Kuala Nerus, Terengganu, Malaysia \\ *Corresponding author: sofiah@umt.edu.my
}

Received: 16 April 2017; Accepted: 7 March 2018

\begin{abstract}
As a new technology, Immobilized Metal Affinity Chromatographic Membrane (IMAC) has proven its efficiency for protein purification. It is also a separation technique that use covalently bound chelating compounds on the membrane supports to immobilize metal ions, which serve as affinity ligands for various proteins. This study aims to prepare and characterize highly specific IMAC for trypsin separation. Chitosan and polyethylene glycol were used as modification solutions to impart the membrane porosity and flux recovery ratio (FRR) of IMAC matrix. The modified PSf with chitosan improved its FRR up to $82.11 \%$ which indicated that PSf/Chitosan was a suitable matrix for the affinity membrane. Glutaraldehyde and $\mathrm{Cu}^{2+} \mathrm{served} \mathrm{as}$ crosslinker agents and affinity ligands respectively. Maximum immobilization capacity of $\mathrm{Cu}^{2+}$ occurred at $120 \mathrm{ppm}$ within 60 minutes' incubation time. The optimum capacity of trypsin adsorption $\left(12.67 \mathrm{mg} / \mathrm{cm}^{2}\right)$ onto IMAC membrane occurred when 0.3 $\mathrm{M}$ ionic strength of trypsin solution was used. Desorption of the enzyme by displacing salt of potassium chloride showed the highest trypsin recovery at $72.3 \%$.
\end{abstract}

Keywords: affinity, chitosan, membrane, trypsin, ultrafiltration

\begin{abstract}
Abstrak
Sebagai teknologi baru, Membran Kromatografi Afiniti Logam Dipegun (IMAC) telah membuktikan kecekapannya untuk penulenan protein. Ia juga merupakan teknik pemisahan yang menggunakan sebatian pelekat yang terikat secara kovalen pada membran sokongan untuk pegunkan ion logam, yang berfungsi sebagai ligan afiniti untuk pelbagai protein. Kajian ini bertujuan untuk menyediakan dan mencirikan IMAC yang sangat spesifik untuk pemisahan trypsin. Kitosan dan polietilen glikol digunakan sebagai larutan pengubahsuai bagi meningkatkan keliangan membran dan nisbah pemulihan fluks (FRR) matriks IMAC. PSf yang telah diubah suai dengan kitosan telah meningkatkan FRR sehingga $82.11 \%$ yang menunjukkan bahawa PSf/kitosan adalah matrik yang sesuai untuk membran afiniti. Glutaraldehid dan $\mathrm{Cu}^{2+}$ masing-masing berfungsi sebagai agen silangan dan ligan afiniti. Kapasiti imobilisasi maksimum $\mathrm{Cu}^{2+}$ berlaku pada $120 \mathrm{ppm}$ dalam masa inkubasi selama 60 minit. Kapasiti jerapan trypsin paling optimum $\left(12.67 \mathrm{mg} / \mathrm{cm}^{2}\right)$ ke atas membran IMAC berlaku apabila $0.3 \mathrm{M}$ larutan tripsin digunakan. Penyerapan enzim dengan menggunakan garam gantian kalium klorida menunjukkan dapatan tripsin paling tinggi iaitu kira-kira $72.3 \%$.
\end{abstract}

Kata kunci: afiniti, kitosan, membran, tripsin, penurasan-ultra 


\section{Sofiah et al: IMMOBILIZED METAL AFFINITY CHROMATOGRAPHIC MEMBRANE FOR TRYPSIN SEPARATION}

\section{Introduction}

There is a growing trend of widening the use of proteolytic enzymes as precursors in their production and commercialization in the fields of food, biopharmaceuticals and biotechnology. There are many methods for enzyme separation and purification in order to achieve good selectivity which includes ion exchange chromatography, affinity chromatography and centrifugation. Those separation techniques have their limitations and the best technique is determined as achieving the best technology of enzyme purification. Affinity chromatography has been considered as one of the essential alternatives and has been utilized many years ago in the aspect of separating and of purifying a wide variety of proteins. Indeed, affinity chromatography is a well-established method for the identification, purification, and separation of macromolecules based on highly specific molecular recognition. Immobilized metal affinity (IMA) absorbents provide moderate affinity to macromolecules by covalently coupling chelating compounds on solid supports to entrap metal ions.

In affinity chromatography, the matrix could affect the activity and stability of the biomolecules, such as proteins and enzymes attached to the matrix [1]. Thus, selection of the supporting matrix is the first important consideration in affinity systems. The matrix must show extremely low nonspecific adsorption, which may be due to charged or hydrophobic groups on its surface, which compromise the specificity of the affinity sorbent. This is essential because the power of affinity sorption relies on specific interaction between the immobilized ligand and the target molecules within the adsorption medium. The matrix must have functional surface groups such as hydroxyl, carboxyl, or amide for further derivation and immobilization of ligands.

Classical matrices for IMAC are based on soft-gels, such as cross-linked dextran and agarose which are compressible and restricted to low flow rate in chromatography operations. Besides, there are many drawbacks by utilizing soft gels such as cross-linked dextran and agarose used in affinity chromatography. It requires the process to apply only low flow rates as to prevent gel deformation and allow mass transfer. The sample must also be clarified before being loaded onto the column. Such traditional multistage protocols may span several days, resulting in large yield loss, contributing to protein sample "aging" and denaturation, as well as involve high operational costs.

Therefore, polymeric membranes such as polysulfone can serve as an excellent matrix for IMAC. This is due to the concern that the membrane process can offer many advantages such as no intra-particle diffusion, short axialdiffusion path, low pressure drops, no bed compaction, and easier scale up. It is highly expected to provide an alternative to the conventional packed-column systems [2-5]. Although this polymer membrane material is proven to have good chemical, thermal and mechanical stability, unfortunately it is lack of reactive functional groups on the polymer backbones [6-7]. Furthermore, the hydrophobic nature of polysulfone results in the adsorption and deposition of hydrophobic solutes on the membrane surface [8] which consequently causes severe membrane fouling, during enzyme production. A thick gel layer forms on the surface, which blocks the membrane's pores, reduces flux and shortens the life of the membrane. This phenomenon deteriorates the membrane and diminishes its separation performance, thereby reducing production efficiency and increasing operating costs. Modified PSf membranes have been widely explored, including both surface modifications (e.g. hydrophilicity improvement) [9, 10] and material modifications (e.g. polymer blends) [11]. Most of the techniques introduced have still not overcome the problems regarding separation performance, process complexity, manufacturing costs and membrane stability. Therefore, the fabricated membrane from polysulfone needs to be modified to eliminate the non-specific type of adsorption as well as to enhance the separation efficiency through improved adsorptive surfaces, especially for biomolecules such as proteins.

The modification of fabricated membrane using hydrophobic material (polysulfone) with hydrophilic material (chitosan) is vital because it can improve membrane performance and is bio-fouling resistant. This is because membrane fouling is still a major problem in spite of much research devoted to its reduction and elimination [8]. There are some reports that have stated that the chitosan has been used as a membrane forming material in preventing any membrane fouling because of its hydrophilic nature and very high affinity for water.

Chitosan (CS), a biopolymer widely available from seafood processing waste, has been increasingly studied as an adsorptive material for a wide range of applications; starting from the dietary regime constituents, food packaging 
materials, drug release components and for environmental pollutants among others [12-14]. Chitosan is an important biomass prepared by the de-acetylation of chitin mainly obtained from crab and shrimp shell and is an amino polysaccharide that is useful in chemical modifications because it has reactive amino and hydroxyl groups [15]. Chitosan has been considered as a potential chromatographic matrix for the presence of free amino and hydroxyl groups on its polysaccharide chain, which provides active reaction sites for the easily coupling of various affinity ligands or ion exchange ligands. Chitosan has many useful features such as hydrophilicity, biocompatibility and anti-bacterial property. This biopolymer is also a well-known adsorbent and is effective in the adsorption of proteins and metal ions since the amino $\left(-\mathrm{NH}_{2}\right)$ and hydroxyl $(-\mathrm{OH})$ groups on chitosan chains can serve as electrostatic interaction and coordination sites, respectively [16]. Moreover, the biomaterials have been proven to possess high performance as a matrix for enzyme separation [17].

In this study, ultrafiltration membrane was fabricated using polysulfone membrane and modified by chitosan and polyethylene glycol to improve its properties. Immobilization capacity of metal ion $\left(\mathrm{Cu}^{2+}\right)$ at different concentrations onto the selected IMAC Matrix was also studied to determine the optimum ligand concentration for IMAC membrane. Trypsin which was dissolved in different ionic strength buffers was used as model protein to evaluate the performance of the prepared IMAC membrane. While, the final stage focused on the effect of displacing salt in elution buffer which affected the trypsin recovery.

\section{Materials}

\section{Materials and Methods}

All materials used in this research are of analytical grade. In this research, the polymer polysulfone (PSf) was used to develop the affinity membrane. The polymer was mixed together with solvent, N-methyl-2-pyrrolidone (NMP) supplied by Merck and ultrapure water $\left(\mathrm{H}_{2} \mathrm{O}\right)$, which acts as non-solvent and provides a coagulation medium. Chitosan $(\mathrm{CH})$ low molecular weight used to modify the affinity membrane was supplied from Aldrich. Polyethylene glycol (PEG) with molecular weight $(20,000)$ was obtained from UMT Research Laboratory, Department of Engineering Science. Acetic acids $\left(\mathrm{C}_{2} \mathrm{H}_{4} \mathrm{O}_{2}\right)$, ethanol $\left(\mathrm{C}_{2} \mathrm{H}_{6} 0\right)$, sodium hydroxide $(\mathrm{NaOH})$, sodium chloride $\left(\mathrm{NaCl}\right.$, ammonia $\left(\mathrm{NH}_{3}\right)$ and distilled water were used for the preparation of affinity membrane for IMAC matrix e.g. $\mathrm{NaCl}$.

\section{Membrane fabrication}

The materials used in ternary dope preparation are the same with the materials used in the binary dope preparation: polysulfone (PSf) as the polymer, N-methyl-2-Pyrrolidone (NMP) as the solvent and water $\left(\mathrm{H}_{2} \mathrm{O}\right)$ as the nonsolvent. The initial stage of preparation is also similar with binary dope preparations; the only difference is the formulation used. Water was added when all the polymers had dissolved, and its amount determined by cloud point. A stirrer was used as to completely dissolve all materials. The polymer must be prepared without any damage. By that, during the dope preparation, the temperature of electrical heating mantel was controlled not to exceed $60{ }^{\circ} \mathrm{C}$. After 8 hours, the polymer solution was placed into an ultrasonic bath to remove trapped air bubbles. The prepared dope solution was stored in Schott bottle.

\section{Membrane surface modification, membrane activation and IMAC membrane preparation}

The modification of the asymmetric PSf membrane is necessary as to enhance the performance of the membrane as well as to reduce the fouling. Membranes were fabricated via simple dry/wet phase inversion technique. The fabrication membranes were done by using the electrically casting machine at shear rate $200 \mathrm{~ms}^{-1}$ and then immersed directly into a coagulation bath for 24 hours. Membrane surface modification was employed using modification solution containing 50\% w/v chitosan and 50\% v/v polyethylene glycol. The dipped time of native PSf membrane was at the optimum time of 60 minutes. This stage was performed as to deposit the chitosan and PEG particles onto the membrane surface. After the dipped time was over, the membrane was dried at room temperature. The membrane was then neutralized with $\mathrm{NaOH}$ solution $(0.1 \mathrm{M}$ in $50 \%$ water-ethanol mixture) for 30 minutes, rinsed with 50\% ethanol solution 3 times and followed by washing with distilled water. PSf/CH/PEG was served as IMAC matrix for further study.

For membrane activation, the prepared matrix was immersed in $100 \mathrm{~mL}$ buffer $(0.1 \mathrm{M}$ sodium chloride and $0.1 \mathrm{M}$ sodium acetate-acetic acid $\mathrm{pH} 7.4$ ) and $100 \mathrm{~mL}$ of $25 \% \mathrm{v} / \mathrm{v}$ glutaraldehyde aqueous solution. The system was 
occasionally stirred and allowed to react for 150 minutes at $30^{\circ} \mathrm{C}$. After the reaction, the excess of glutaraldehyde was removed by washing the membranes three times with a $2 \mathrm{M}$ acetic acid solution.

The metal ion used was copper(II) sulfate anhydrous $\left(\mathrm{CuSO}_{4}\right)$ and all procedures were carried out based on different concentrations of $30 \mathrm{ppm}, 60 \mathrm{ppm}, 90 \mathrm{ppm}, 120 \mathrm{ppm}$ and $150 \mathrm{ppm}$ and was prepared in distilled water. The modified PSf chitosan membranes were placed in the metal ion solution with stirring $100 \mathrm{rpm}$ at room temperature and were immobilized onto the activated membrane for 150 minutes immobilization time. The adsorption capacity was determined for every 30-minute interval.

\section{Membrane characterization}

Membrane characterization studies were performed in terms of pure water permeability, membrane morphology using scanning electron microscopy (SEM), and functional groups on the membrane surface assessed using Fouriertransform infrared spectroscopy equipped with attenuated total reflection (ATR-FTIR). In SEM studies, membranes samples were first immersed in liquid nitrogen and then fractured membranes for preparing samples. The SEM samples were then deposited with gold using an Auto Fine Coater before scanning. The chemical functional groups of membrane surface were determined using Fourier Transform Infra-Red Spectroscopy (FTIR). FTIR spectra of the modified membrane were obtained using the FTIR spectrophotometer at Physic Laboratory, University Malaysia Terengganu. The dry membranes of about $0.1 \mathrm{~g}$ were thoroughly mixed with $\mathrm{KBr}$ and pressed into pellet form. The FTIR spectrum was recorded.

\section{Adsorption of trypsin onto IMAC membrane}

Trypsin was used as a model protein. $0.5 \mathrm{mg} / \mathrm{mL}$ of trypsin solution was prepared by dissolving trypsin in $0.1 \mathrm{M}$ phosphate buffer solution at $\mathrm{pH} 8$ at room temperature. Ionic strength studies were carried out by the adding different concentrations of $\mathrm{NaCl}(0.01 \mathrm{M}, 0.05 \mathrm{M}, 0.1 \mathrm{M}, 0.3 \mathrm{M}$ and $0.5 \mathrm{M})$. This experiment was conducted in triplicates for 150 minutes with stirring $100 \mathrm{rpm}$ at room temperature and was started after immersion of membrane disk in the trypsin solution. The concentration of trypsin was measured at $595 \mathrm{~nm}$ by using UV-Vis spectrophotometer. The amount of adsorbed trypsin on the affinity membranes were obtained by using the following equation 1:

$$
\mathrm{q}=\frac{\left(\mathrm{C}_{\mathrm{o}}-\mathrm{C}\right) \mathrm{V}_{\underline{\mathrm{S}}}}{\mathrm{A}}
$$

where $\mathrm{q}$ is the amount of trypsin adsorbed onto membranes $\left(\mathrm{mg} / \mathrm{cm}^{2}\right), \mathrm{C}_{\mathrm{o}}$ and $\mathrm{C}$ are the concentration of the total protein in the initial and final solutions after adsorption $(\mathrm{mg} / \mathrm{mL})$ respectively. $\mathrm{V}_{\mathrm{s}}$ is the volume of aqueous solution $(\mathrm{mL})$ and $\mathrm{A}$ is the area of the membranes in the adsorption medium $\left(\mathrm{cm}^{2}\right)$.

\section{Properties of IMAC matrix}

\section{Results and Discussion}

Native PSf and modified PSf, which served as IMAC matrices, were characterized in terms of permeability coefficient, membrane porosity, fouling quantification, surface morphology and FTIR analysis.

Table 1. Permeability Coefficient of Native and Modified PSf

\begin{tabular}{lcccc}
\hline $\begin{array}{l}\text { Membrane } \\
\text { ID }\end{array}$ & $\begin{array}{c}\text { Permeability } \\
\text { Coefficient } \\
\left(\mathbf{L} / \mathbf{m}^{2} . \text { h.bar }\right)\end{array}$ & $\begin{array}{c}\text { Regression } \\
\text { Coefficient }\left(\mathbf{R}^{2}\right)\end{array}$ & $\begin{array}{c}\text { Membrane } \\
\text { Porosity (\%) }\end{array}$ & $\begin{array}{c}\text { Flux Recovery } \\
\text { Ratio (\%) }\end{array}$ \\
\hline PSf 15 & 75.932 & 0.9931 & 82.67 & 53.03 \\
CH-50/PEG-50/PSf & 70.445 & 0.9968 & 77.06 & 82.11 \\
\hline
\end{tabular}


There are only slightly decreased in permeability coefficient and membrane porosity between native and modified PSf. However, modification of PSf with chitosan and PEG successfully improved the flux recovery ratio (FRR) of the modified membrane by $29.1 \%$. This result indicates that the modified PSf membrane was more suitable to serve as IMAC matrix since it has a low tendency for fouling phenomenon due to the high percentage of FRR and high porosity membrane. Chitosan or its derivatives are known as excellent antifouling agents, and surface coating is the simplest method for the modification of membranes to achieve a good antifouling property. Besides, PEG also has been introduced to improve the anti-fouling properties of PSf membrane. Moreover, PEG can increase the hydrophilicity of the membrane and this has been supported by Rana et al. [18] which states that the improvement in hydrophilicity of the membrane surface is confirmed as an effective and popular method for fouling resistance.

\section{Characteristics of IMAC membrane}

The asymmetric membrane can be seen clearly with the presence of the active layer and the support layer. The active layer of the membrane consists of a thin skin while the supporting structure is the layer below the skin due to the rapid solvent precipitation during the phase inversion process. The morphology of membrane surface and cross section for the IMAC membrane are shown in Figure 1. Figure 1(a) represents the surface morphology of IMAC membrane. The IMAC membrane shows a rough and porous surface structure which can provide a high adsorption capacity of the enzyme. Trypsin inhibitors were successfully immobilized onto the PSf/chitosan membrane using the activation with glutaraldehyde.
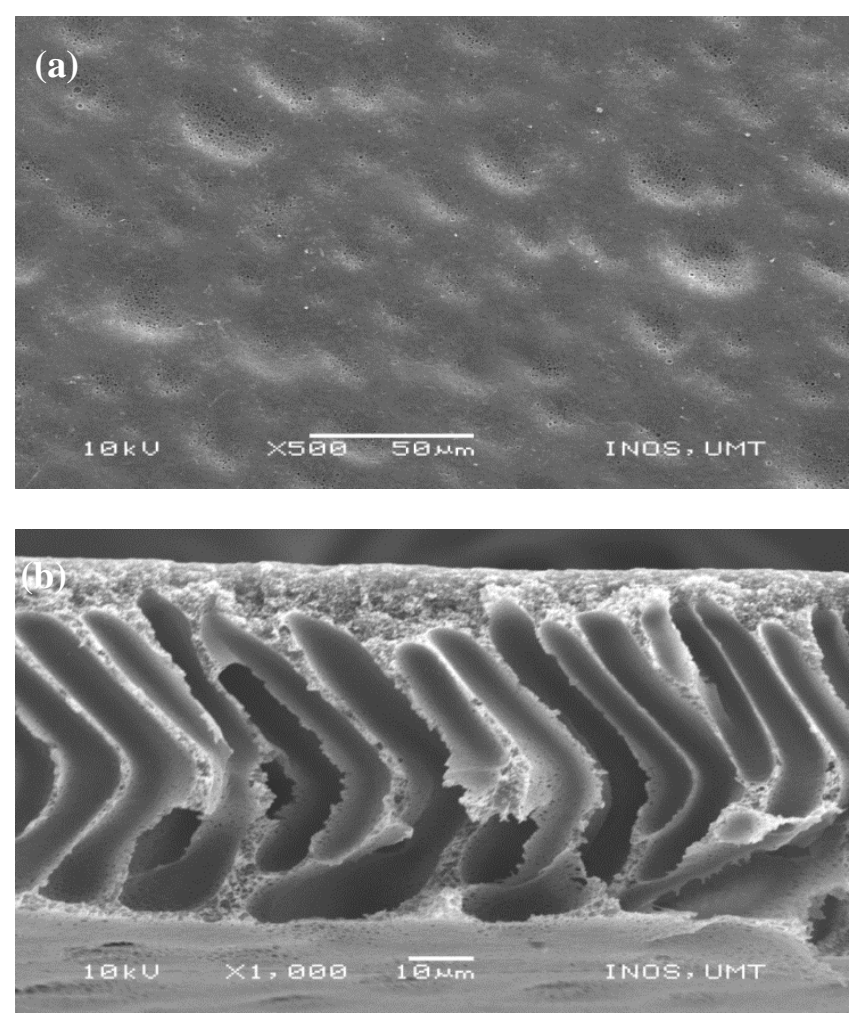

Figure 1. Morphology of (a) IMAC surface and (b) IMAC cross section

The cross section of developed pores and finger-like structures were observed from the thin skin until the support layer for all cases. The affinity membrane with immersion method shows a relative thick skin layer on the membrane skin due the remains of metal ion ligands that bound on the skin surface. To verify the functional group of membrane surface, IMAC membrane was also characterized by using ATR-FTIR and the result shows in Figure 2 . 

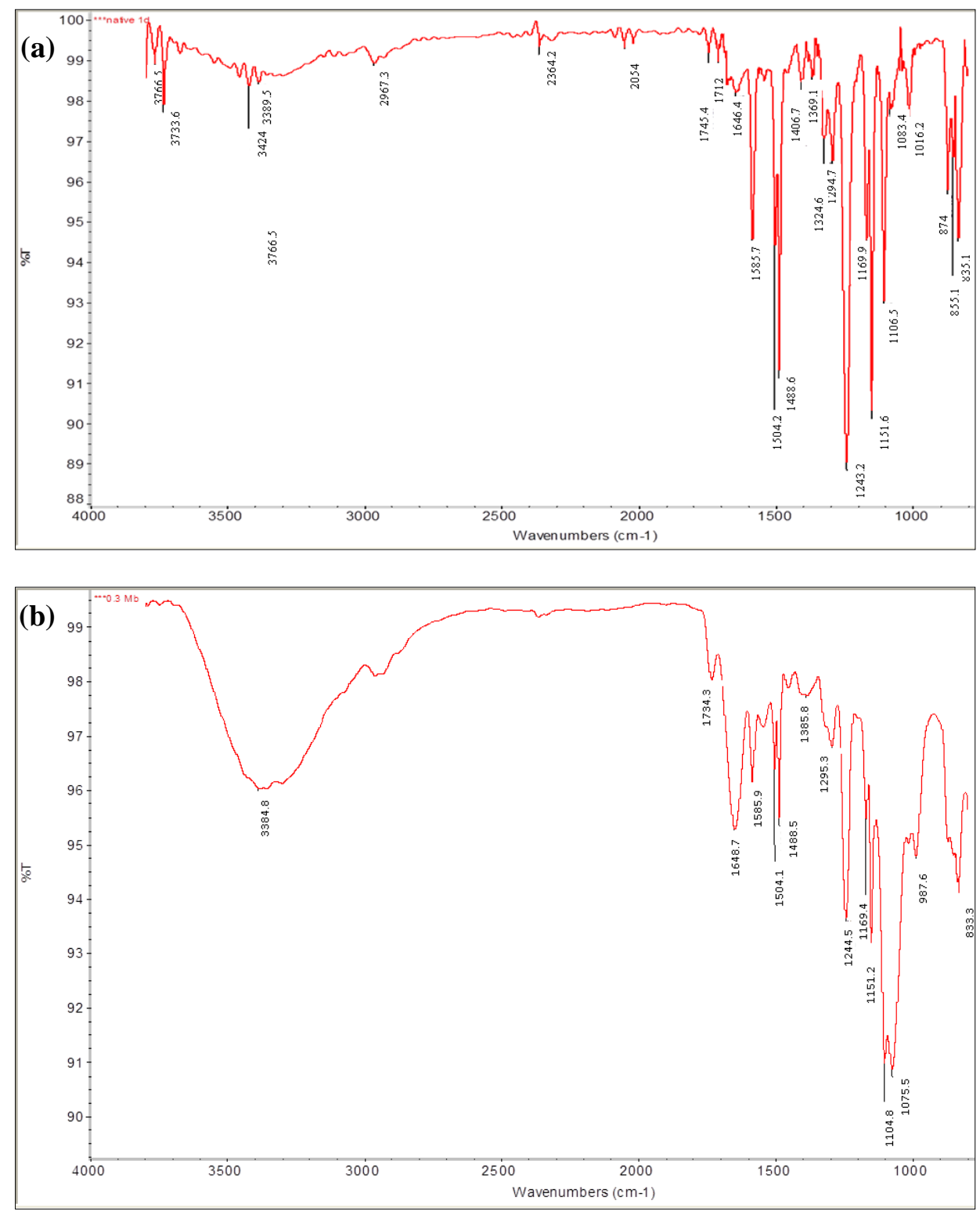

Figure 2. ATR - FTIR spectra of (a) Native PSf15 and (b) IMAC membrane

The new bands coming after membrane modification indicates the presence of a thin layer deposited on top of the PSf15 membrane. For the unmodified membrane, the absorption peaks at $1504 \mathrm{~cm}^{-1}$ are characteristic of polysulfone membrane. This shows that the weak bands are due to methyl groups and they present exclusively on the spectrum of polysulfone. The band range from $3424-3733 \mathrm{~cm}^{-1}$ shows the presence of the amine groups occurring in the polymer polysulfone. The band appearing at $3389 \mathrm{~cm}^{-1}$ is attributed to $\mathrm{NH}_{2}$ and $\mathrm{O}-\mathrm{H}$ of the $\mathrm{N}$-acetyl group in chitosan particle where it ranges from 3200-3600 of spectra. This may be due to the slight hydrolysis of the sulfone group of the pristine PSf membrane by $\mathrm{NaOH}$ which occurs during the membrane neutralization process. The band at $1743 \mathrm{~cm}^{-1}$ in the spectra were due to ethylenic chain and this explains the presence of the aldehyde peaks in the developed affinity membrane. The presence of saccharide of chitosan in the affinity membrane around $987.6 \mathrm{~cm}^{-1}$ indicates that the surface of membrane was coated by the chitosan. 


\section{Immobilization capacity of metal ion $\mathrm{Cu}^{2+}$ onto IMAC matrix}

Metal ion concentration is one of the most important factors to influence adsorption behavior. As observed in Figure 3 , an increase in the ligand concentration has led to an increase of immobilization capacity up to 120 ppm ligand. Rapid adsorption can be seen within the first $30 \mathrm{~min}$ and afterwards. In all cases, the interactions slowed down, approached equilibrium and began to decrease in nearly 60 to $90 \mathrm{~min}$ under the given set of experimental conditions. The maximum capacity for the metal ion immobilization was $0.875 \mathrm{mg} / \mathrm{cm}^{2}$ using $120 \mathrm{ppm}$ concentration. This shows that the high concentration of ligand could provide more surface available sites for enzyme binding and better adsorption can be performed.

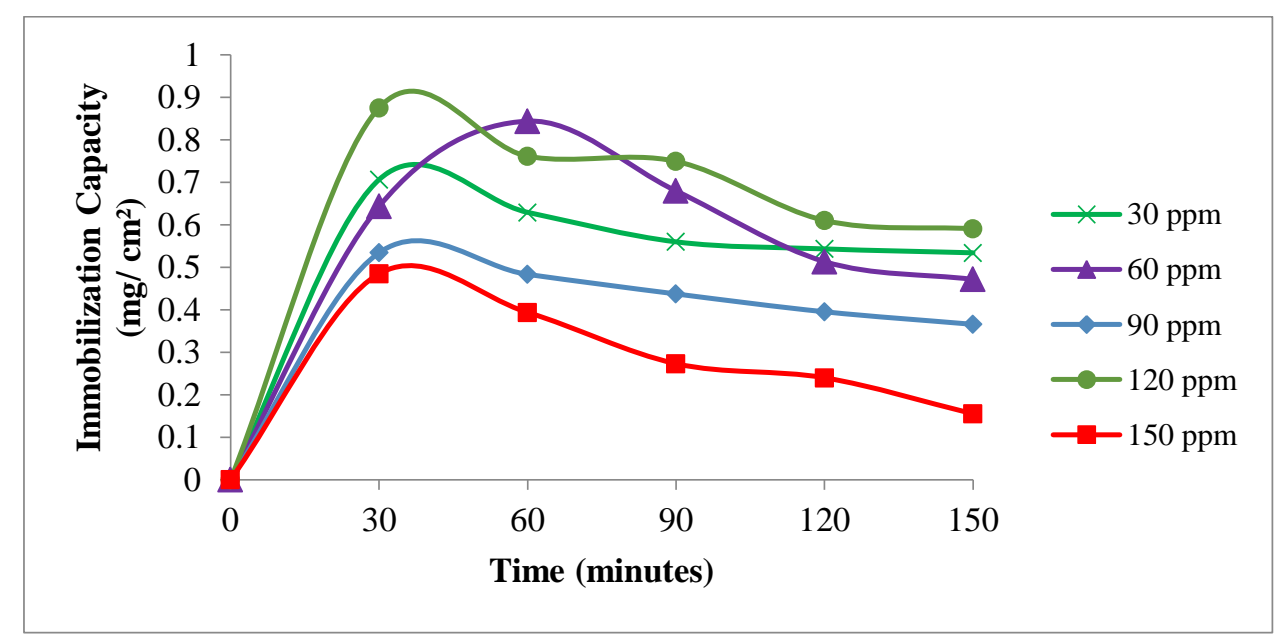

Figure 3. The effect of different concentrations of copper on its immobilization capacity onto IMAC matrix

However, for the higher concentration of metal ion which was $150 \mathrm{ppm}$, the efficiency of immobilization was reduced due to the excess of metal ions that cannot be bound with the membrane. The decrease of adsorption capacity was most likely to be caused by the precipitation of excess $\mathrm{Cu}$ (II) and free $\mathrm{Cu}$ (II) inhibiting the protein by forming a complex compound.

\section{Trypsin adsorption onto IMAC membrane at different ionic strength}

The effect of ionic strength on the adsorption of trypsin onto IMAC membrane was studied by using different concentrations of $\mathrm{NaCl}$, ranging from $0.01 \mathrm{M}$ until $0.5 \mathrm{M}$ in a buffer solution ( $\mathrm{pH}$ 8). The amount of trypsin adsorbed was measured with enzyme concentrations determined before and after adsorption. The result obtained is shown in Figure 4.

The adsorption behavior of IMAC membrane is suppressed in the presence of salt. As seen in Figure 4, the value of the immobilization capacity for each trypsin adsorption was reduced with increasing salt concentration. The maximum trypsin adsorption was obtained at $0.3 \mathrm{M}$ in 120 minutes with $12.67 \mathrm{mg} / \mathrm{cm}^{2}$ adsorption capacity. In all cases, the adsorption slowed down and started to decrease in about 90 to 120 minutes under the given set of experimental conditions. The adsorption behavior in this study occurred mostly by electrostatic interactions between the trypsin molecules and membranes. The electrostatic interaction between protein molecules and metal chelated affinity system are reduced by the presence of salt due to the screening charge on protein surfaces [17]. This is the reason why the experiment was performed at $\mathrm{pH} 8$, as to ensure that the electrostatic attraction between the surface and the metal chelated was high.

An increase in ionic strength also causes a change in the interaction mechanism due to more contributions from hydrophobic and protein-protein interactions [4]. In the higher salt concentration range, enzyme solubility generally decreases due to the reduced activity of water and the neutralization of surface charge. At higher ionic strength, the 
protein will be dehydrated due to the hydrated effect of salt molecules surrounding the protein allowing the hydrophobic interactions to contribute.

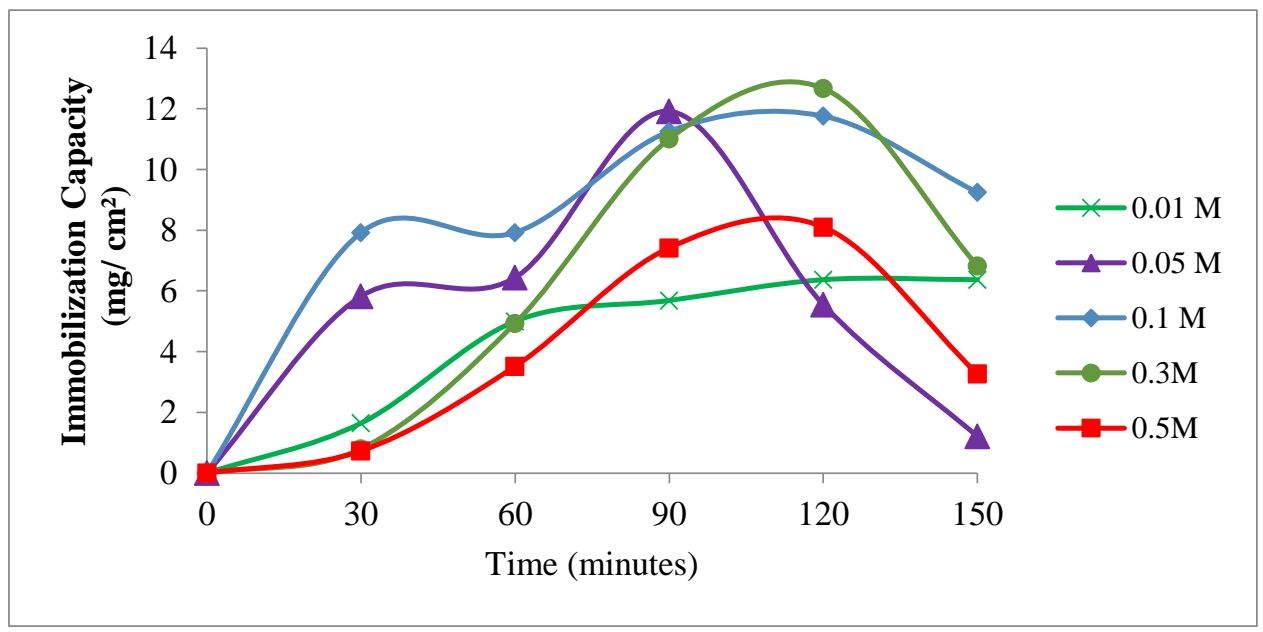

Figure 4. The effect of ionic strength on the adsorption capacity of trypsin onto IMAC

\section{The influence of displacing salt in elution buffer}

The elution strength of an eluent is the ability to elute solutes from the affinity membrane and is determined by the concentration and type of ionic species in the eluent. Different salts used give different elution strength. Therefore, the prospective salts to be used had to fulfill several conditions to qualify for evaluation in this study. These conditions are essentially demands that have to be met for a salt to make it useful in practice. In this study, four types of displacing salt were used, including $\mathrm{KCl}, \mathrm{NaCl}, \mathrm{ZnCl}$ and $\mathrm{CaCl}$ with $0.05 \mathrm{M}$ ionic strength. Figure 5 shows the total protein, total activity and purity of trypsin obtained after affinity ultrafiltration process and Figure 6 shows the trypsin recovery.

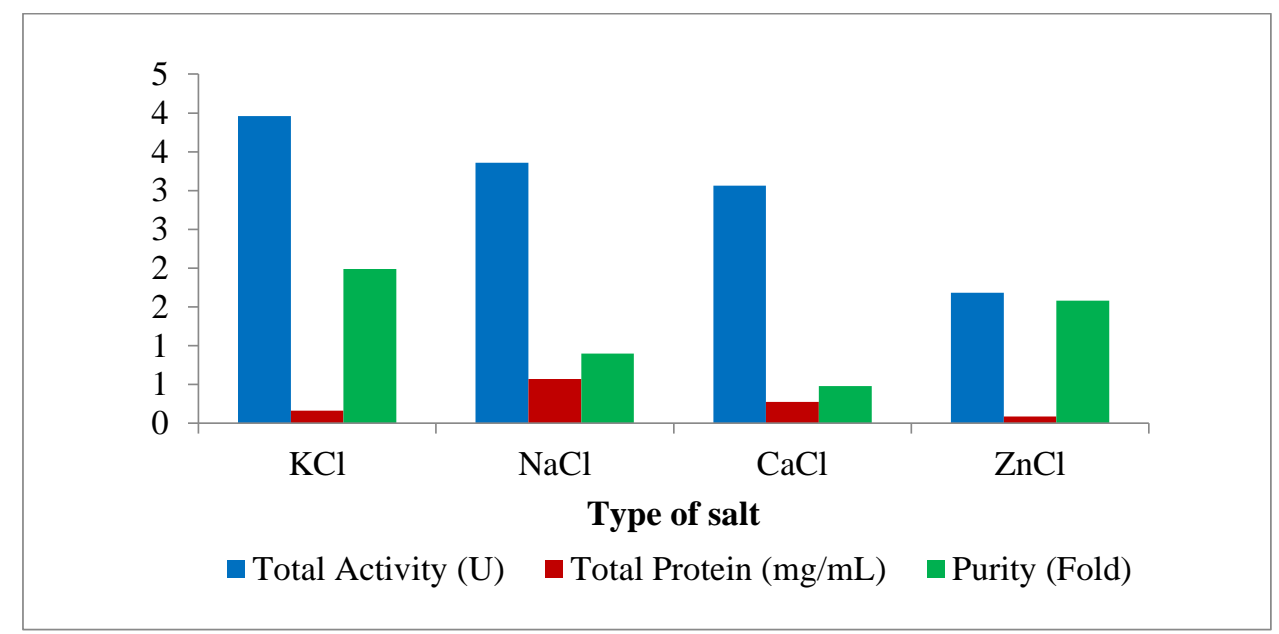

Figure 5. Total protein, total activity and purity of trypsin after affinity ultrafiltration with different type of displacing salt 


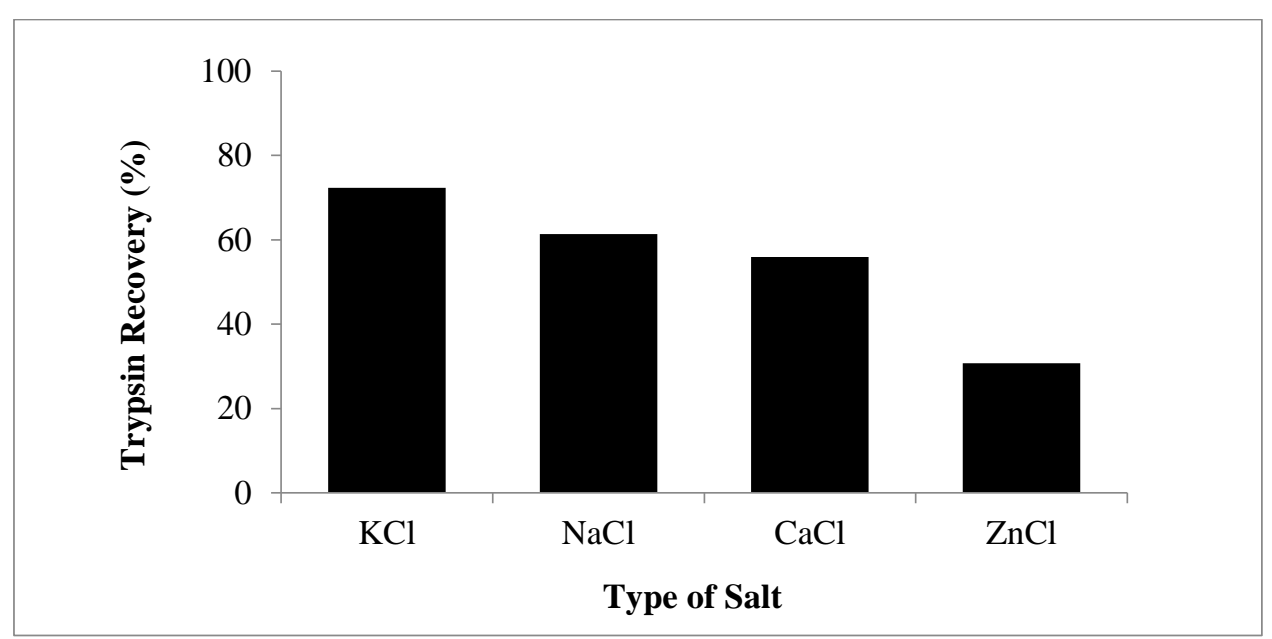

Figure 6. Trypsin recovery using affinity ultrafiltration membrane with different displacing salt

The results show that the different salts added give a major effect on trypsin recovery. Potassium chloride has the highest trypsin recovery for about $72.3 \%$ with 1.99 purification fold. Sodium chloride only recovered $61.4 \%$ trypsin. The ionized salts in this study are classified as chaotropes and kosmotropes. The term kosmotrope refers to salts that stabilize protein structure while chaotropes are salts that destabilize protein structures. The potassium has been expected to be the highest since it is one of the chaotropes ion. Besides that, the cationic properties also affect the experimental values. Since potassium and sodium are in group 1 in the periodic table, they are alkali metals and are among the most reactive metals. They tend to donate their electrons in reactions and have oxidation state of +1 . Since the position of potassium in periodic table is below the sodium, where the activity increases down the group, potassium is more reactive, oxidizes easily and is able to separate the bonding between the trypsin and its ligand, allowing for higher amount of trypsin to be passed through the affinity membrane.

The least significant trypsin recovery was observed when zinc chloride was used as additional salt in the elution buffer which is at $30.7 \%$ only. As observed, the addition of zinc chloride to the elution buffer caused the solution to become cloudy due to incomplete ionization and had affected the reading of total protein. Moreover, zinc is a kosmotropes which promotes hydrophobic reaction. Zinc is in the transition metal group on the periodic table and is less reactive than other ions used, which can be ranked in descending order as $\mathrm{K}>\mathrm{Na}>\mathrm{Ca}>\mathrm{Zn}$. This results in the difficulty of breaking the bond between the trypsin and its ligand and reducing the transmission during the elution process.

\section{Conclusion}

In this study, the preparation and characterization of immobilized metal affinity chromatography (IMAC) matrix for trypsin separation and purification had been successfully developed. The most significant changes in membrane properties and separation performance had been performed by CH-50/PEG-50/PSf membrane and is considered as an optimum condition for membrane surface modification. This membrane is modified with the self-assembly of $50 \%$ of chitosan and 50\% PEG in the modifying formulation. Combination of chitosan and PEG had improved the hydrophilicity of membranes and flux recovery ratio at about $29.01 \%$. In addition, high porosity and excellent performance during trypsin permeation had promoted this membrane as a good matrix for affinity membrane development. Optimum ligand concentration for maximum immobilization capacity was $120 \mathrm{ppm} \mathrm{Cu}^{2+}$. The highest trypsin adsorption obtained was $12.67 \mathrm{mg} / \mathrm{cm}^{2}$ by using $0.3 \mathrm{M}$ ionic strength of trypsin solution. Desorption of the enzyme by using displacing salt of potassium chloride was successfully recovered about $72.3 \%$ trypsin. Hence, it can be concluded that objectives in this study had been successfully achieved. The outcome from this study is a part of the contribution for further development in affinity membrane development. 


\section{Acknowledgement}

Authors want to express a high gratitude to Ministry of Higher Education Malaysia for the funding of this research (ERGS 55097) and University Malaysia Terengganu for all supports and contributions.

\section{References}

1. Jianmin, W., Fengna, X. and Qingfu, Y. (2005). Separation and purification of Cry1Ab protein expressed from Bt transgenic plants. Chinese Journal of Analytical Chemistry, 33(7): 927-930.

2. Yang, P., Chen, C., Wang, Z., Fan, B. and Chen, Z. (1999). A pathogen- and salicylic acid-induced WRKY DNA-binding activity recognizes the elicitor response element to the tobacco class I chitinase gene promoter. The Plant Journal, 18(3): 141-149.

3. Zou, H., Luo, Q. and Zhou, D. (2001). Affinity membrane chromatography for the analysis and purification of proteins. Journal of Biochemical and Biophysical Methods, 49(1-3): 199-240.

4. Wu, C. Y., Suen, S. Y., Chen, S. C. and Tzeng, J. H. (2003). Analysis of protein adsorption on regenerated cellulose-based immobilized metal affinity membranes. Journal of Chromatography A, 996 (1-2): 53-70.

5. Hu, H. L., Wang, M. Y., Chung, C. H. and Suen, S. Y. (2006). Purification of VP3 protein of infectious bursal disease virus using nickel ion immobilized regenerated cellulose-based membranes. Journal of Chromatography B, 840(2): 76-84.

6. Jiraratananon, R., Chanachai, A. and Huang, R. Y. M. (2002). Pervaporation dehydration of ethanol-water mixtures with chitosan/hydroxyethylcellulose (CS/HEC) composite membranes: II. Analysis of mass transport. Journal of Membrane Science, 199(1-2): 211-222.

7. Liu, C. X. and Bai, R. B. (2005). Preparation of chitosan/cellulose acetate blend hollow fibers for adsorptive performance. Journal of Membrane Science, 267(1-2): 68-77.

8. Ramesh, B. P. and Gaikar, V. G. (2001). Membrane characteristics as determinant in fouling of UF membranes. Separation Purification Technology, 24(1-2): 23-34.

9. Gancarz, I., Zniak, G. P., Bryjak, M. and Tylus, W. (2002). Modification of polysulfone membranes. Effect of n-butylamine and allylamine plasma. European Polymer Journal, 38(10): 1937-1946.

10. Hamzah, S., Ali, N., Mohammad, A. W., Ariffin, M. A. and Ali, A. (2012). Design of Chitosan /PSf selfassembly membrane to mitigate fouling and enhance performance in trypsin separation. Journal of Chemical Technology and Biotechnology, 87(8): 1157-1166.

11. Ali, A., Yunus, M. R, Awang, M. and Mat, R. (2015). Effect of shear rate on characteristics, performance and morphology of polysulfone blend membranes. Applied Mechanics and Materials, 699: 305-310.

12. Arvanitoyannis, I., Nakayama, A. and Aiba, S. (1998). Chitosan and gelatin based edible films: State diagrams, mechanical and permeation properties. Carbohydrate Polymer, 37(4): 371-382.

13. Arvanitoyannis, I. (1999). Totally and partially biodegradable polymer blends based on natural and synthetic macromolecules: preparation, physical properties, and potential as food packaging materials. Journal of Macromolecular Science, Part C, 39(2):205-271.

14. Sashiwa H. and Aiba S. (2004). Chemically modified chitin and chitosan as biomaterials. Progress in Polymer Science (Oxford), 29(9): 887-908.

15. Sashiwa, H., Fujishima, S. and Yamano, N. (2003). Enzymatic production of $n$-acetyl-d-glucosamine from chitin. degradation study of $n$-acetylchitooligosaccharide and the effect of mixing of crude enzymes. Carbohydrate Polymer, 51(4): 391-395.

16. Saxena, S., Gupta, B., Arora, A. and Alam, M. S. (2006). Chitosan-polyetylene glycol coated cotton membranes for wound dressings. Indian Journal of Fibre and Textile Research, 36(3): 272-280.

17. Bayramoğlu, G. and Yakup, A. M. (2002). Procion green H-4G immobilized on a new IPN hydrogel membrane composed of poly (2-hydroxyethylmethacrylate)/chitosan: preparation and its application to the adsorption of lysozyme. Colloids and Surfaces A: Physicochemical and Engineering Aspects, 202 (1): 41-52.

18. Rana, T. M. (1994). Artificial proteolysis by a metal chelate: Methodology and mechanism. Advanced Inorganic Biochemical, 10: 177-200. 